\title{
Representation of People with HIV/AIDS in The Jakarta Post and Jakarta Globe: A Critical Discourse Analysis
}

\author{
Gigit Eklesia ${ }^{1}$, Akhyar Rido ${ }^{2}$ \\ gigitteknokrat@gmail.com ${ }^{1}$, akhyar_rido@teknokrat.ac.id ${ }^{2}$ \\ Universitas Teknokrat Indonesia
}

\begin{abstract}
This study aims to understand representational meanings from the transitivity choices used by news reports from The Jakarta Post and Jakarta Globe in reporting people with HIV-positive cases and exposing the underlying ideology behind the representation. Fairclough's three-dimensional concept in Critical Discourse Analysis (CDA) was applied in this study. The study also relied on Halliday's systemic functional grammar, particularly in the transitivity analysis. Two selected articles were collected from The Jakarta Post and Jakarta Globe newspapers. The findings revealed that both news media dominantly report people with HIV/AIDS through material process, then followed by verbal process and relational process. Next, the study found that people with HIV/AIDS are represented as discriminated and threatened group in The Jakarta Post; meanwhile, they are represented as a mistreated group in Jakarta Globe. Last, the study found that The Jakarta Post attempts to construct that people with HIV/AIDS need to be more accepted and protected; meanwhile, Jakarta Globe attempts to construct an idea that people with HIV/AIDS need to be given more attention. To sum up, the combination of the both theories is substantially advantageous in the discourse to expose ideology.
\end{abstract}

Keywords: representation, three-dimensional model, transitivity

\section{Introduction}

Discourse is described as structure and practices which represent human thought and social realities through particular collections of words and that construct certain meaning in the world (Fairclough, 2003). As one of the approaches in a discourse, critical discourse analysis is an analysis that sees how texts in social and political contexts are raised (Van Dijk, 2004 in Suprayogi \& Pranoto, 2020). Hence, as a study in the linguistics field, linguistics features such as vocabulary, grammar, and text structure are imperative to be clearly analyzed. Since considered as discourse that widely spread in society, newspaper has strongly linked to power and ideology. Hence, the perspective of society is always influenced by information contained in newspaper (Pekkarinen, 2016 in Evayani \& Rido, 2019). As many people depend on newspaper as a source of information, it has significant influence or impact on how individuals and society construct stigmas toward certain individuals, culture, illness and etc.

Accordingly, it is considered imperative to demonstrate how stigmatized group such as people with HIV/AIDS (Human Immunodeficiency Viruses/ Acquired Immune Deficiency Syndrome) in particular is represented in newspaper as Ren (2017) argues that mass media plays a significant role in shaping people's views of such illnesses and disorders, including HIV / AIDS. Despite the positive impact of the media in mitigating stigma, the literature has reported that the media could perpetuate HIV stigma in public discourse. People with HIV/AIDS are more likely get unfair treatment from the environment, avoided, rejected and expelled (Indonesian Social Change Organization, 2011). This stigma has longly and strongly been embedded in society which caused discrimination toward people living with HIV. Therefore, since reported as credible Indonesian English News and have the potentials to be globally read (Tarrant, 2008 in Utami, 2018), The Jakarta Post and 
Jakarta Globe were chosen by the researchers to reveal how people with HIV-positive being represented in Indonesia news media.

Moreover, Some critical discourse studies on newspaper articles have been conducted. Utami (2018) analyzed how LGBT (lesbian, gay, bisexual, and transgender) represented in The Jakarta Pos and Jakarta Globe. The findings indicate that the two media are trying to convince their readers to recognize LGBT's presence in Indonesia as a marginalized group. Moreover, Isti' anah (2015) conducted an investigation towards the language use in people's opinions of capital punishment for drug convicts in The Jakarta Post. The result confirms that the ideologies revealed in the opinions are power, pessimism, and criticism.

To this end, this study aims to derive representational meanings from the transitivity choices used by news reports from The Jakarta Post and Jakarta Globe in reporting people with HIV-positive cases and understanding the underlying ideology behind the representation. this study employs Fairclough's three-dimensional concept in Critical Discourse Analysis (CDA). Furthermore, this study also relies on Halliday's systemic functional grammar, particularly in the transitivity analysis. This study is expected to give an insight to the readers of how media produces discourses which contain certain ideologies.

\section{Theory and Method}

The current research particularly applied qualitative descriptive research method. This type of approach would also devote a great deal of interpretation to the context and the situation (Stake, 2010 in Kuswoyo \& Rido, 2019) using Fairclough's model of CDA. The objective of the model is to describe formal properties of text, to interpret the relationship between text and interaction, and to explain the relationship between the interaction and social context (Fairclough, 1995).

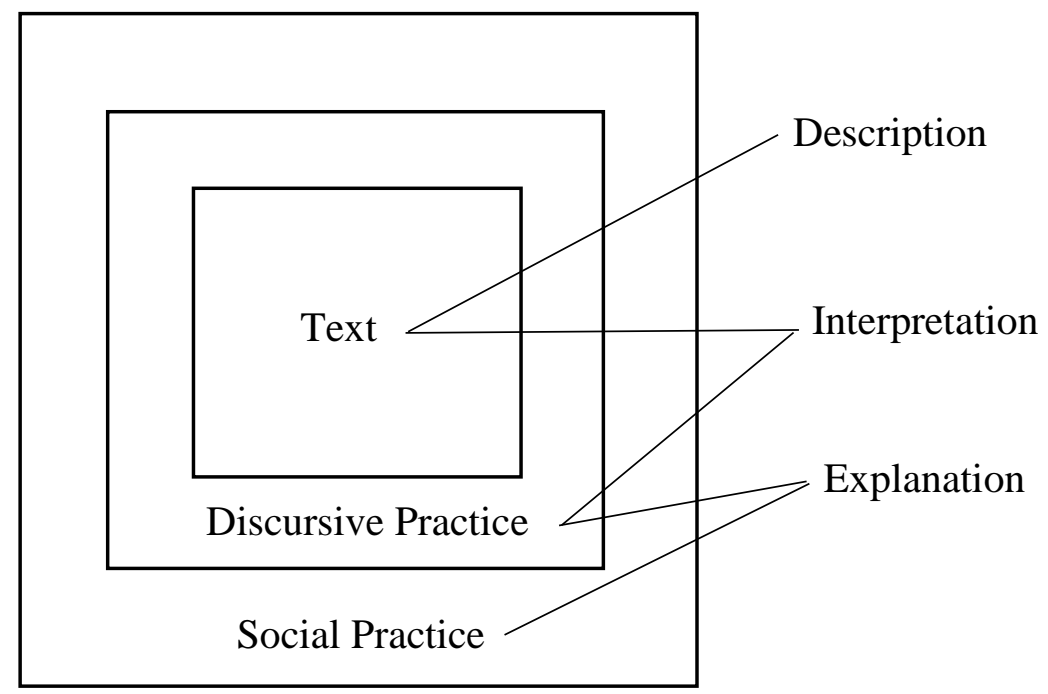

Fairclough's Three-dimensional Model (1995)

This study specifically aimed to derive representational meanings from the transitivity choices used by news reports from The Jakarta Post and Jakarta Globe in reporting people with HIV-positive cases and exposing the underlying ideology behind the representation. The data sources were The Jakarta Post and Jakarta Globe Newspaper. Moreover, the data were in the form of clauses which were taken from selected articles. The articles were selected based on news covering "people with HIV/AIDS". The range of the data was taken from 2009 (the first article about HIV/AIDS was published) - 2019. Due to limited time and space, there were 2 articles selected in this study. 


\section{Data Collection}

This study employed library research as the primary data collection method. According to Zeid (2004) in Ilahi and Rusman (2019), Library research is a search of literature by using library tools to collect research data. Therefore, there were several steps conducted to collect the data. First, the researchers collected the data by browsing all news reports related to people with HIV/AIDS including children with HIV/AIDS in Indonesia published by Jakarta Globe (http://jakartaglobe.id) and the Jakarta Post (http://www.thejakartapost.com). Both The Jakarta Post and Jakarta Globe published reports on people with HIV/AIDS around 7 and 100 news reports respectively. Second was sorting out the news reports. The basic consideration in deciding which news reports to be analyzed is that the news reports should be able to represent people with HIV throughout time: the very first time issues on people with-HIV positive were brought to the media, the heated moments of people with HIV reports, and etc. Third, the news reports of the two media based on the selected issues were collected. There are 2 news reports chosen in this study.

\section{Data Analysis}

Content analysis was used as the methodology to analyze the data. According to Krippendorff's (2004) in Kuswoyo and Rido (2019), there are four stages involved in the data analysis: The first is identifying the data. In this stage, the researcher conducted textual analysis which relies on Halliday's systemic functional grammar, which is transitivity. Transitivity is described as a grammatical structure that defines the clauses as representations (Halliday \& Matthiessen, 2004 in Utami 2018), thus, the researchers broke down the texts into clauses and identified each clauses into types of transitivity process.

According to Halliday (1985), there are six types of transitivity process, they are, material, mental, relational, behavioral, verbal, and existential. Next, each different types of process was identified and encoded by numbering and initialing the sets of clause sequences which appear in the data, for example; $1 / \mathrm{b} / \mathrm{MA}$.

Table 1. Example of Coding used in Data Analysis (Kuswoyo \& Rido, 2019:89)

\begin{tabular}{|c|c|}
\hline The code & The data \\
\hline 1/b/MA & $\begin{array}{l}\text { People with HIV (ODHA) in the country still face } \\
\text { rampant stigmatization and discrimination }\end{array}$ \\
\hline \multicolumn{2}{|c|}{$\begin{array}{l}1,2,3, \ldots=\text { number of paragraph sequence } \\
\mathrm{a}, \mathrm{b}, \mathrm{c}, \ldots=\text { clause sequence } \\
\mathrm{MA}=\text { Material; } \mathrm{ME}=\text { Mental } ; \mathrm{RE}=\text { Relational } \mathrm{BE}=\text { Behavioral } ; \mathrm{EX}= \\
\text { Existential; } \mathrm{VE}=\text { Verbal }\end{array}$} \\
\hline
\end{tabular}

Second is classifying the data. After the data had been identified, each types of transitivity process was classified in the form of table. This stage was conducted in order to help the researchers easier in analyzing the data. The example of the data classififcation was ilustrated as follows:

Table 2. Example of the data classification

\begin{tabular}{|c|c|c|c|c|c|c|c|c|}
\hline \multirow{2}{*}{ No } & \multirow{2}{*}{ Code } & \multicolumn{2}{|c|}{ Data } & \multicolumn{4}{|c|}{ Type of Transitivity process } \\
\cline { 4 - 8 } & & MA & ME & RE & BE & EX & VE \\
\hline 1 & $1 / \mathrm{a} / \mathrm{MA}$ & $\begin{array}{l}\text { Purwotomo 74 public elementary } \\
\text { school in Surakarta, Central Java, } \\
\text { expelled 14 students }\end{array}$ & $\checkmark$ & & & & & \\
\hline
\end{tabular}




\begin{tabular}{|c|l|l|l|l|l|l|l|l|}
\hline 2 & $1 / \mathrm{b} / \mathrm{RE}$ & $\begin{array}{l}14 \text { students were identified as } \\
\text { positive for HIV/AIDS }\end{array}$ & & & $\checkmark$ & & & $\checkmark$ \\
\hline 3 & $2 / \mathrm{a} / \mathrm{BE}$ & $\begin{array}{l}\text { Parents and guardians of other } \\
\text { students allegedly threatened the } \\
\text { school management }\end{array}$ & & $\checkmark$ & & & & \\
\hline
\end{tabular}

The researchers counted the total number of each types of transitivity and present the results in the form of precentage. The results of the precentage was presented in the form of chart so that the total of different transitivity process types could be clearly understood. Third id analyzing the data. Fairclough's three dimensional model was employed to analyze the data. Fairclough (1995) proposes three models in analyzing a discourse: description (text analysis), interpretation (processing analysis) and explanation (social analysis). The last is presenting the findings.

\section{Findings and Discussion}

This study investigated the representation of people with HIV/AIDS which are published in The Jakarta Post and Jakarta Globe online newspaper by employing three dimensional model of Fairclough (1995). Fairclough proposes three models in analyzing a discourse: (1) Description (text analysis), in this stage, Halliday's transitivity analysis is used as analytical tool in anayzing the discourse. (2) Interpretation (processing analysis), in this stage, the linguistics features from the transitivity analysis are related to the interaction that will produce concepts or themes reflected from the news reports. (3) Explanation (social analysis), in this stage, the concepts or themes found in the interpretation will be connected to the social context that will reveal the hidden ideologies.

The first part will describe the results of the transitivity analysis of The Jakarta Post and Jakarta Globe news reports. There are two articles chosen from both news media, the two articles are entitled "People with HIV in Indonesia face rampant workplace discrimination" published in The Jakarta Post and "People With HIV in Asia Ejected From hospitals, Women Sterilized: Study" published in Jakarta Globe. From the news reports, the researchers found 41 clauses from The Jakarta Post and 52 clauses from Jakarta Globe.

The first is The Jakarta Post news articles. The total processes of transitivity types occured in The Jakarta post article are 41 times. From the analysis, it was revealed that The Jakarta Post dominantly reports people with HIV/AIDS issue through material process that is $41 \%$ with 17 times of occurances, followed by verbal process $37 \%$ or 15 times, and relational process with $15 \%$ or 6 times of occurances. For the mental, behavioral and existential contribute $2 \%$ of each process or only occur once in the news report.

Meanwhile, in the Jakarta Globe, it was 52 transitivity processes found in the news article. Similar to The Jakarta Post, Jakarta Globe dominantly reports people with HIV/AIDS through material process that is $38 \%$ or occur 20 times. It was followed by verbal process with $31 \%$ or 16 times, third was relational process with $21 \%$ or 11 times. Next was mental process with $10 \%$ or 5 times of occurances. Meanwhile, there was no behavioral and exitential process in Jakarta Globe news article.

\section{Description}

Description is the stage which is concerned with formal properties of text (Fairclough 1989). Description is the stage of text analysis. The stage is used to reveal the patterns of the linguistics features in the text and to find the meaning of the patterns. The linguistics features of the text such as vocabulary, grammar and text structure are need to be considered in this stage. This study concerns to the grammatical features, which has close relation to Halliday's 
systemic functional grammar. As Fairclough (2003:27) stated representation corresponds to Halliday's ideational function, transitivity in particular. Thus, this study considered transitivity as the analytical tool for conducting critical discourse analysis, particularly in the first part of Firclough's three-dimensional model, description. In transitivity, there are three elements of what Halliday calls a process, they are: the process itself, participants in the process; and circumstances associated with the process. These elements are used to describe the real-world depiction of phenomena through linguistic structures. Thus, the transitivity process found in the first finding serve as linguistics features in this description stage. Thus, the findings of the previous transitivity analysis are described in this section more detail.

\section{Material Process}

Material process is a process of "happening, creating, or doing" which involves actions either concrete or abstract action. There are two participants role in the material process, namely: actor and goal. Actor is the one who performs the action, while goal is the one which affected by the process.

\section{Material Process in The Jakarta Post}

The findings show that material process reach the highest precentage which occur in the text report compare to the other processes. According to Halliday and Matthiessen (2004: 192) in Utami (2018), material processes "express the notion that some entity 'does' something - which may be 'to' some other entity". In the text, the material process are mostly used by The Jakarta Post to describe people with HIV/AIDS as the one who performs miserable action and also the one who affected by some immoderate action. The example of the material process are presented below.

Datum $1(1 / \mathrm{b} / \mathrm{MA})$

\begin{tabular}{|c|c|c|}
\hline Actor & Process & \multicolumn{1}{|c|}{ Goal } \\
\hline $\begin{array}{c}\text { People with HIV (ODHA) in the } \\
\text { country }\end{array}$ & still face & $\begin{array}{l}\text { rampant stigmatization and } \\
\text { discrimination in the workplace. }\end{array}$ \\
\hline
\end{tabular}

The datum above indicates the occurrence of material process in the text. The material process is described by the verb "still face". In this case, the verb "still face" indicates the process of doing which is done by the actor "people with HIV (ODHA) in the cauntry" and directed at "rampant stigmatization and discrimination in the workplace" as the goal. This process describes that people with HIV/AIDS in certain country still face such a miserable action like stigmatization and discrimination. Then, the next material process is shown as follows.

Datum 2 (2/c/MA)

\begin{tabular}{|c|c|c|}
\hline Actor & Process & Goal \\
\hline One of her patients & had recently experienced & such discrimination \\
\hline
\end{tabular}

The datum above shows another material process in the text. The material process is indicated from the verb "had recently experienced". In the process, "one of her patient" is indicated as the actor, while "such descrimination" is the goal. The clause describes people with HIV/AIDS which represented with the noun "patient" had experienced discrimination.

\section{Material Process in Jakarta Globe}

Similar to The Jakarta Post, material process also reach the highest precentage which occur in the text report of Jakarta Globe compare to the other processes. As in the news 
report, the material process are used by Jakarta Globe to emphasize that people with HIV/AIDS are the victim of descrimination through the position (goal) of the participants as well as Jakarta Globe also emphasizes the mistreated experiences of people with HIV/AIDS through the position of actor. The example of the material process are presented below.

Datum $3(1 / \mathrm{b} / \mathrm{MA})$

\begin{tabular}{|c|c|c|}
\hline Actor & Process & Goal \\
\hline Some health workers in Asia & are expelling & patients from hospitals \\
\hline
\end{tabular}

The datum above shows that material process occur in the Jakarta Globe news article. The material process is described by the verb "are expelling". In this case, the verb "are expelling" indicates the process of doing which is done by the actor "some health workers in Asia" and directed at "patients from hospital" as the goal. This clause describes how health workers do mistreated act towards people with HIV/AIDS who reported as patient from hospital in the text. Next, another material process is presented below.

Datum 4 (3/a/MA)

\begin{tabular}{|c|c|c|}
\hline Goal & Process & \\
\hline Patients with HIV & were relegated to segregated & waiting areas and bed spaces \\
\hline
\end{tabular}

The clause above contains material analysis, yet the actor was not specifically mentioned in the text. Since the clause is in passive voice, the goal is positioned in the begining of the clause. The material process is indicated from the verb "were relegated to segregated", while the goal is "patient with HIV". Simply, the clause indicates that somebody relegate to segregate people with HIV.

\section{Verbal Process}

Verbal process is process of saying. There are three participants of this process, there are sayer (the one who speak), receiver (the one who receive the talk), verbiage (the name of the verbalization itself), and target (the one who targeted by the process).

\section{Verbal Process in The Jakarta Post}

The verbal process used in The Jakarta Post describe some verbal action that used by some organizations and activists to indicate people with HIV/AIDS. The data of verbal process are presented in the explanation below.

Datum $5(1 / \mathrm{a} / \mathrm{VE})$

\begin{tabular}{|c|c|c|}
\hline Sayer & Process & verbiage \\
\hline Activists & $\begin{array}{c}\text { have } \\
\text { revealed }\end{array}$ & $\begin{array}{c}\text { that people with HIV (ODHA) in the country still face rampant } \\
\text { stigmatization and discrimination in the workplace }\end{array}$ \\
\hline
\end{tabular}

The datum above shows that The Jakarta Post news report contains verbal process. The verbal process is indicated from the verb "have revealed". The sayer in the clause is "activist" which verbalized the verbiage "that people with HIV (ODHA) in the country still face rampant stigmatization and discrimination in the workplace". The clause does not mention the receiver, yet from the context, the verbalization is addressed to the reporter. This data describes how activist told the reporter about the fact of what have been experienced by people with HIV/AIDS. Next, another verbal process is presented below. 
Datum $6(2 / \mathrm{b} / \mathrm{VE})$

\begin{tabular}{|c|c|c|}
\hline Sayer & Process & Verbiage \\
\hline $\begin{array}{c}\text { Maya Tri Siswati, a doctor who has } \\
\text { treated ODHA since 2000, }\end{array}$ & said & $\begin{array}{c}\text { one of her patients had recently } \\
\text { experienced such discrimination ... }\end{array}$ \\
\hline
\end{tabular}

The sentence above consists of several clauses which the main verb belongs to verbal process. The verbal process is indicated from the verb " said", while the syaer is "Maya Tri Siswati". The process describes that there is a doctor who told about an incident of her patient living with HIV/AIDS.

\section{Verbal Process in Jakarta Globe}

Verbal process are also found in Jakarta Globe as the second highest process appear in the text. The verbal process in Jakarta Globe are used to indicate people with HIV/AIDS as receiver of discrimination which are addressed by the medical staff, Jakarta Globe attempts to represent people with HIV/AIDS as victim of mistreated done by society including medical staff. The data of the verbal process in Jakarta Globe are presented below.

Datum $7(1 / \mathrm{a} / \mathrm{VE})$

\begin{tabular}{|c|c|c|c|}
\hline Sayer & Process & verbiage & receiver \\
\hline $\begin{array}{c}\text { Some health workers } \\
\text { in Asia }\end{array}$ & are refusing & $\begin{array}{c}\text { to perform surgery and } \\
\text { provide services }\end{array}$ & $\begin{array}{c}\text { for people living } \\
\text { with HIV }\end{array}$ \\
\hline
\end{tabular}

From the datum above, verbal process are contains in the clause. The process is encoded through the verb "are refusing" in the datum. Here, the sayer is "Some health workers in Asia" as the one who tell. The receiver is "people living with HIV" and the verbiage is "to perform surgery and provide services". The datum describes how health workers refuse to do proper treatment toward people with HIV/AIDS. Then, the next verbal process contains in Jakarta Globe is presented below.

Datum 8 (3/b/VE)

\begin{tabular}{|c|c|c|}
\hline Sayer & Process & verbiage \\
\hline One HIV-positive woman in Myanmar & said & $\begin{array}{c}\text { doctors told staff not to give her a } \\
\text { hospital bed }\end{array}$ \\
\hline
\end{tabular}

Datum $9(3 / \mathrm{c} / \mathrm{VE})$

\begin{tabular}{|c|c|c|c|}
\hline Sayer & Process & receiver & verbiage \\
\hline doctors & told & staff & not to give her a hospital bed \\
\hline
\end{tabular}

The datum 8 above is a sentence which contains another clause as a complement. In the datum 8 , the process is identified from the verb "said" while the sayer is "One HIVpositive woman in Myanma". Moreover, the verbiage in datum 8 is encoded through the clause "doctors told staff not to give her a hospital bed" in which the clause also consist od verbal process whihc identified by datum 9 . The verbal process in the datum 9 is encoded through th verb "told" with the sayer is "doctors", the receiver is "staff" and the verbiage is "not to give her a hospital bed". The sentence which contains two verbal process above describes about how a person with HIV/AIDS explain her experiences of how her doctors treated her in the hospital. 


\section{Relational Process}

Relational process is a process of being and having. According to Halliday and Matthiessen (2004: 211) the main characteristic of relational processes is that it relates a participant to its identity or description. Therefore, the process is devided into two types: attributive relation and identifying relation. The attributive relation relates to the what properties or categories are attributed to the participant. While identifying relation relates to the identity establishment. The attributive relation has two participants, they are carrier and attribute. Meanwhile, identifying relation also has two participants, they are identified and identifier.

\section{Relational Process in The Jakarta Post}

Relational process is the third most occurrence process in The Jakarta Post. The relational process in The Jakarta Post are used to describe the identity of people with HIV and their right. The types of relational process that occur in The jakarta Post are circumstantial and possessive. The data explanations are presented as follows.

Datum $10(3 / \mathrm{b} / \mathrm{RE})$

\begin{tabular}{|c|c|c|}
\hline Carrier & Process & Attribute \\
\hline $\begin{array}{c}\text { discrimination against people with } \\
\text { HIV/AIDS }\end{array}$ & is & $\begin{array}{c}\text { still rampant in the } \\
\text { workplace }\end{array}$ \\
\hline
\end{tabular}

The clause above shows that relational process occur in the text report. From the datum, the relational process is identified by the verb "is", while the carrier is identified by the phrase "discrimination against people with HIV/AIDS". Next, the attribute is identified from the phrase "still rampant in the workplace". The datum describes the circumstances of people with HIV/AIDS in the workplace where the discrimination still exists.

\section{Relational Process in Jakarta Globe}

Relational process is also the third most occurrence process in Jakarta Globe news report. The relational process in Jakarta Globe are mostly used to describe the status of people with HIV/AIDS and the status of their right. The both types of relational process occur in Jakarta Globe. The explanation of relational process which occur in news report are presented as follows.

Datum $11(5 / \mathrm{a} / \mathrm{RE})$

\begin{tabular}{|c|c|c|}
\hline Identifier & Process & Identified \\
\hline The Asia-Pacific region & is & home to 4.8 million people living with HIV \\
\hline
\end{tabular}

The datum above shows that relational process occur in Jakarta Globe. The types of relational process which is shown above is identifying relational. The relational process is shown through the verb "is". Here, the identifier is "The Asia-Pacific region", while the identified is "home to 4.8 million people living with HIV". The clause describes the right of people with HIV/AIDS. The datum shows that Asia-Pacific region is identified as the home of people with HIV/AIDS.

\section{Interpretation}

The next stage to answer the problem statements is through interpretation. Interpretation is the stage of connecting textual analysis and social analysis. In this stage, the researchers relate the linguistics features found from the transitivity analysis to the interaction which produces theme reflected from the text. In addition, intertextual context is 
also conducted as Fairclough (1989) assumes that interpretation is examined through the combination of situational context and intertextual context. In other words, this stage is conducted to reveal the representation in the clauses by connecting the pattern of transitivity process, the situational context and intertextual context.

\section{Interpretation of the Article in The Jakarta Post}

The Jakarta Post represents people with HIV/AIDS as discriminated people. Discrimination refers to the act of prejudicial treatment toward certain community or group, so that people who get discriminated are unfairly treated. The Jakarta Post attempts to describe the discrimination through the material process and verbal process. Halliday and Matthiessen $(2004 ; 192)$ stated that material processes "express the notion that some entity 'does' something - which may be 'to' some other entity". In this case, it is depicted that the material process express the notion that people with HIV/AIDS 'do' something - 'to' discrimination. Moreover, the verbal process are used to describe the facts of what is happening towards people with HIV/AIDS. The verbal process are mostly uttered by activist, medical staff and some organizations that intend to defend people with HIV/AIDS. The example of the process are presented below.

Datum 12 (1/a/VE, 1/b/MA)

Activists have revealed that people with HIV (ODHA) in the country still face rampant stigmatization and discrimination in the workplace.

Datum 13 (2/a/Ma, 2/b/VE, 2/c/MA)

Maya Tri Siswati, a doctor who has treated ODHA since 2000, said One of her patients had recently experienced such discrimination.

The examples above are sentences that produced by The Jakarta Post in reporting people with HIV/AIDS. The sentences consist of several process which indicated as verbal process and material process. The clause reflect the idea of discrimination that experienced and faced by people with HIV/AIDS by using material process. Moreover, the material process itself were uttered by activist and a doctor to convey the idea as a fact that is happening in which the utterences are considered as the verbal process. The Jakarta Post represents people with HIV/AIDS as discriminated community through fact that uttered by some other communities. This finding may be similar to Utami's (2018) study, where material process is more frequently used in The Jakarta Post news report. The findings further describe that material process are mostly used by The Jakarta Post as the way to defend certain communities. In line with Isti'anah's (2015) findings, the material process also appear frequently to defend certain party by The Jakarta Post.

Moreover, The Jakarta Post also represent people with HIV/AIDS as a threatened group. The threat are described coming from the environment, such as workplace and even coming from the health care provider, in which people with HIV/AIDS are more likely unable to get proper health treatment. This idea is reflected through some transitivity process, particularly in the relational process. Relational process is a process of being and having, the process relates the participant to its identity or description. Here are the example of the relational process in The Jakarta Post.

Datum 14 (3/b/RE)

Discrimination against people with HIV/AIDS is still rampant in the workplace. 


\section{Datum 15 (13/b/RE)}

The number of people who were being treated for the disease was extremely low.

The above sentences imply that the idea of people with HIV/AIDS as threatened group through relational process. The first datum describes the circumstances of people with HIV/AIDS in the workplace where the discrimination still exists and the second datum describes the low number of people with HIV/AIDS get medical teratment. Thus, The Jakarta Post is also assumed to represent people with HIV/AIDS as threatened group, which coming from both environment and medical services.

\section{Interpretation of Article in Jakarta Globe}

Meanwhile in Jakarta Globe, people with HIV/AIDS are represented as mistreated group. The mistreatment here refers to the fact of being treated badly and unfairly. Jakarta Globe describe how people with HIV/AIDS are being treated badly, unfairly, or even cruely by some health care providers. Jakarta Globe attempts to describe the mistreatment in the news report through material process. Material process is a process of "doing," which is expressed by an action verb, an actor, and the goal of the action (Halliday 1985). In the Jakarta Globe news report, the material process are encoded by using some verbs such as "expelling, relegated and segregated", while the verbs are expressed by the actors who are health workers, and the process are addressed to people with HIV/AIDS. This way is used to emphasize the mistreatment which are suffered by people with HIV/AIDS. The quotations of the material process are presented as follow.

Datum 16 (1/b/MA, 1/c/MA)

Some health workers in Asia ... are even expelling patients from hospitals and forcing women to undergo sterilization.

Datum 17 (3/a/MA)

Patients with HIV were relegated to segregated waiting areas and bed spaces.

The quotations above are produced by Jakarta Globe to describe how people with HIV/AIDS are mistreated. Through material process, people with HIV/AIDS are positioned as the goal of negative action verbs which refers to mistreatment and discrimination. This findings is also similar to Utami's (2018) study, Jakarta Globe mostly used material process to describe certain communities as a victim of certain bad action.

Moreover, the representation of people with HIV/AIDS as mistreated group is also expressed through verbal process. The verbal process in Jakarta Globe are used to express the utterence of people with HIV/AIDS in describing their mistreatment experiences. The datum of the verbal process are presented below.

Datum $18(3 / \mathrm{b} / \mathrm{VE})$

One HIV-positive woman in Myanmar said doctors told staff not to give her a hospital bed.

The sentence above shows how a woman with HIV positive described her experiences of being mistreated. The verbal process are used to emphasize the mistreatment of people with HIV/AIDS as it is uttered by the one who experienced the mistreatment itself.

\section{Explanation}

Explanation is the final stage in investigating the ideology which constructed in The Jakarta Post and Jakarta Globe. Fairclough (1989:26) states, "Explanation is concerned with the relationship between interaction and social context with the social determination of 
the process of production and interpretation, and their social effects". In other words, it requires the researchers to connect what have been found in the interpretation to the social contexts.

\section{Explanation of Article in The Jakarta Post}

Based on the transitivity interpretations in The Jakarta Post as explained in the previous stage, the media conveys discrimination and threat that are undergone by people with HIV/AIDS. By considering these concepts that reflected in The Jakarta Post, it can be revealed that The Jakarta Post attempts to construct that people with HIV/AIDS need to be more accepted and protected. In this case, The Jakarta post considers that discrimination toward people with HIV/AIDS has long existed and the pervention of the discrimination has long been conducted. However, the discrimination is still happening due to stigma that has been embedded in society. The Jakarta Post emphasizes through the articles that the discrimination is happening in the workplace. According to Indonesia AIDS coalition (2019) there were many people with HIV dissmised from their work because of their status. Even if they were still allowed to work, they would get discrimination from their friends at work. Regard with the target of The Jakarta Post readers who are mostly business people, well educated Indonesia people, and foreigners (Tarrant, 2008), it can be assumed that the readers mostly have significant role to help and support people with HIV/AIDS, including accepting and protecting them.

Study published by UNAIDS (2005) showed that there are numerous direct and indirect links between the HIV epidemic and a lack of human rights protection, some of them are: violations of rights may worsen the impact of HIV, increase vulnerability, and hinder positive responses to the epidemic. For example, a person who is dismissed from his or her job due to HIV-positive, beyond his or her disease, faces several additional problems, including lack of financial resources for his or her health care, as well as caring for any dependent family. Therefore, regarding to these problems, The Jakarta Post more likely intends to suppress the problems faced by people with HIV/AIDS, particularly in the field of workplace to prevent other following problems. Thus, this intention can be achieved by searching protection for people with HIV/AIDS from its readers.

Moreover, a survey that was conducted in Nigeria found that people who have stigma towards people with HIV/AIDS were more likely coming from younger participants, those who have lower education, and those in low socioeconomic status (Dahlui et al, 2015). Interestingly, the survey also found that people with higher education level and people from upper socioeconomic status seem to be more compassionate towards people with HIV/AIDS. Regard to The Jakarta Post target readers, it can be assumed that the ideology constructed by The jakarta Post was embedded to the right communities.

\section{Explanation of Article in Jakarta Globe}

Based on the interpretation of transitivity process, it is found that Jakarta Globe conveys the mistreatment which was done towards people with HIV/AIDS. Considering to this concept, it is revealed that Jakarta Globe attempts to construct an idea that people with HIV/AIDS need to be given more attention, particularly regarding to health treatment. Jakarta Globe attempts to bring up the issue of how people with HIV/AIDS are treated badly and unfairly. Furthermore, misinformation that has long been believed by society has resulted stigma towards people living with HIV/AIDS. HIV/AIDS has long been believed as the results of negative behaviors which could be easily passed on from one person to another. The stigma resulted people with HIV/AIDS get unfair treatment from the environment, avoided, rejected and expelled (Indonesian Social Change Organization, 
2011). From the interpretation in the previous stage, Jakarta Globe seems likely to remind that mistreatment and discrimination towards people with HIV/AIDS as well as some misinformation about HIV/AIDS itself are still occurring nowadays. Moreover, Jakarta Globe emphasized that the mistreatment occur mostly from the health care providers. This is used to affirm that people with HIV/AIDS receive less attention.

HIV/AIDS-related stigma and discrimination research was conducted among health providers such as physicians and nurses attached to different hospitals in Bangladesh. The study shows that $80 \%$ of the nurses and $90 \%$ of the physicians' behavior with the HIVpositive individuals were discriminatory. These health care providers know well about the route of the transmission, yet the fear of being infected still occurs (Ullah, 2011). Moreover, another similar study was also conducted in 4 Asian countries including Indonesia, which found that 54\% people with HIV/AIDS experienced mistreatment and discrimination in the health care sector (Paxton, 2005). Hence, people with HIV/AIDS tend to hide their HIV/AIDS status, in which it might widen the vulnerability of spreading the virus. Thus, to prevent these problems, Jakarta Globe attempts to emphasize the mistreatment that happen in the health sector.

Since discrimination and mistreatment towards people with HIV/AIDS occur in both government and private hospitals, it is assumed that the government, educated people and other influential people pay less attention towards people with HIV/AIDS. Jakarta Globe is marketed primarily at cosmopolitan, well educated Indonesians and expatriates (Mitsalina, 2016). Thus, it can be assumed that Jakarta Globe also has right target readers.

\section{Conclusion}

This study aimed to understand representational meanings from the transitivity choices used by news reports from The Jakarta Post and Jakarta Globe in reporting people with HIV-positive cases and exposing the underlying ideology behind the representation. This study has succesfully reveal the representational meanings and underlying ideology by using Fairclough's three dimensional model and also rellying on Halliday's transitivity analysis which acts as a valuable analytical method used in the text analysis. Based on the results, the researchers formulated some conclusion. First, the study revealed that the both news media dominantly report people with HIV/AIDS through material process, then followed by verbal process and relational process. In the second stage, the study found that people with HIV/AIDS are represented as discriminated and threatened group. While, in Jakarta Globe, they are represented as mistreated group. At the last stage, the study found that The Jakarta Post attempts to construct that people with HIV/AIDS need to be more accepted and protected. Meanwhile, Jakarta Globe attempts to construct an idea that people with HIV/AIDS need to be given more attention.

This study has shown that the transitivity process is indeed capable of revealing the ideology of the news discourse. Moreover, this study could reveal how The Jakarta Post and Jakarta Globe use its texts to represent people with HIV/AIDS and to share certain ideology. As the final outcome, this study has demonstrated that the transitivity process is substantially advantageous in the discourse to expose ideology. For further examination the researchers really suggests that the other researchers may keep following up this interesting combination of two different theories by developing some aspects. The other researchers can utilize another tool such as corpus to produce great textual analysis, as corpus may provide fresh insights further into language use features (Hyland, 2006 in Rido et al, 2020). Thus, this study is expected to give an insight to linguistics researchers to conduct further analysis. 


\section{References}

Afrianto \& Gulö, Ingatan. 2019. Revisiting English competence at hotel. Teknosastik: Jurnal Bahasa dan Sastra, 17(1), 35-39.

Amalia, Rosaria Mita. 2019. Textual analysis of power of the government of Indonesia and Aceh in the Helsinki MoU. Teknosastik: Jurnal Bahasa dan Sastra, 17(1),1-6.

Dahlui, Maznah., Azahar, Nazar, Bulgiba, Awang., Zaki, Rafdzah., Oche, Manshur., Adekunjo, Felix., and Chinna, Karutan. 2015. HIV/AIDS Related Stigma and Discrimination against PLWHA in Nigerian Population. National Center of Biotechnology Information (NCBI), 10(12), 105-200.

Evayani, Widya \& Rido, Akhyar. 2019. Representation of Social Actors in Sexual Violence Issue in The New York Times and The Jakarta Post Newspapers: A Critical Discourse Analysis. Teknosastik: Jurnal Bahasa dan Sastra, 17(2), 43-55.

Ezzina, Rym. 2015. Transitivity Analysis of The Crying lot of 49 by Thomas Pynchon. International Journal of Humanities and Cultural Studies, 2(3), 283-292.

Halliday, M.A.K., \& Matthiessen, M.I.M. 2004. An Introduction to Functional Grammar,

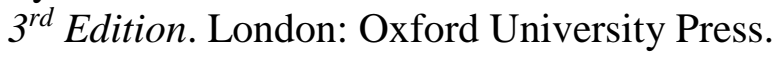

Hamrita, Mouna. 2016. A critical discourse analysis of the representation of Islamists on Facebook pages in post-revolution Tunisia. Philology and Cultural Studies, 9(2), 620.

Handayani et al. 2018. Fairclough's Three Dimension Framework Used on Trump's Political Speech: A Critical Discourse Analysis (A Case Study of Historic Speech Related to Jerussalem as Israel's Capital). Annual International Conference on Language and Literature (AICLL), 1(1), 336-342.

Haratyan, F. 2011. Halliday's SFL and Social Meaning. 2011 2nd International Conference on Humanities, Historical and Social Sciences, 17(2), 260-264.

Kuswoyo, Heri \& Rido, Akhyar. 2020. Process Types of Transitivity System in Engineering Lecture Introduction: A Pedagogic Discourse. Lingua: Jurnal Bahasa dan Sastra, 19(2), 85-98.

Ilahi, Anis \& Rusman. 2019. The Improvement of Technology Ability for Teachers in Learning Activity to Increase Teachers Competencies in 21st Century through Training. (Master's thesis). Indonesia University of Education.

Isti'anah, Arina. 2015. The Language and Ideology of Capital Punishment for Drug Convicts Found in Selected Opinions in The Jakarta Post. A Journal of Culture, English Language Teaching and Literature (Celt), 15(2), 134-164.

Fairclough, N. 1989. Language and Power. New York, NY: Longman Publishing.

Fornkwa, Marcell Jaff. 2015. A Critical Discourse Analysis of newspaper articles on the 2015 state budget of Cameroon in the national press. Yaounde International Symposium on Academic Writing and Mentorship for Juniour Scientists.

Paxton, S., Gonzales, G., Uppakaew, K., Abraham, K.K., Okta, S., Green, C., Nair, K.S., Merati parwati, T., Thepthien. B., Marin, M., and Quesada, A, 2005. AIDS-related discrimination in Asia. AIDS Care, 17(4), 413-424. 
Pranoto, Budi Eko \& Yuwono, Untung. 2017. Leader's attitude towards terrorism A critical discourse analysis of Dr.Mahathir Mohamad's diplomatic letters. Cultural Dynamics in a Globalized World: 65-73.

Ren, Chunbo. 2017. HIV Stigmatization in Chinese Media Discourse and Responses from People Living with HIV in China. World Conference on STDs, STIs \& HIV/AIDS. Allied Academies Journal, 1(2), 17.

Rido, Akhyar. 2010. The use of discourse markers as an interactive feature in lecture discourse in L2 setting. TEFLIN Journal, 21(1), 90-106.

Kuswoyo, Heri, Sujatna, Eva Tuckyta Sari., Indrayani, Lia Maulia, \& Rido, Akhyar, 2020. Cohesive Conjunctions and and so as Discourse Strategies in English Native and NonNative Engineering Lecturers: A Corpus-Based Study. International Journal of Advanced Science and Technology, 29(7), 2322-2335

Mitsalina, Endah. 2016. A Discourse Analysis of Jakarta Globe in Advertisements. ETERNAL (English Teaching Journal), 7(1), 1-8

Suprayogi \& Pranoto, Budi Eko. 2020. Konstruksi Wacana Kasus Pembegalan di Portal Berita Tribun Lampung. Manusia, Bahasa dan Teknologi, 12-32.

Ullah, Ahsan. 2011. HIV/AIDS-Related Stigma and Discrimination: A Study of Health Care Providers in Bangladesh. Journal of the International Association of Physicians in AIDS Care, 10(2), 97-104

United Nation Human Right. 2011. HIV/AIDS and Human Rights. Retrieved from https://www.ohchr.org/ on the $10^{\text {th }}$ of June 2011.

Utami, Meina Astria. 2018. The Representation of LGBT and A Hidden Ideology of The Jakarta Post and Jakarta Globe. Ranah: Jurnal Kajian Bahasa , 7(1), 86-114.

Vaara, E. 2015. Cambridge Handbook of Strategy as Practice. 2nd edition. Cambridge University Press: Cambridge.

Zhang, X. 2013. The third U.S-China strategic and economic dialogue: A contrastive study of Chinese and American newspaper news reporting. (Master's thesis). University of Florida, United States. 